\title{
Learning Model of Helped Discovery Learning Computer Based Instruction (CBI) on Fashion Technology of Fashion Education Study Program of Universitas Negeri Medan
}

\author{
Dina Ampera ${ }^{1}$, Flora Hutapea ${ }^{2}$, Farihah $^{3}$ \\ \{dinaampera@unimed.ac.id ${ }^{1}$ \} \\ Universitas Negeri Medan, Indonesia ${ }^{1,2,3}$
}

\begin{abstract}
This research is a research and development with the aim to determine the effectiveness of Discovery Learning models in the Fashion Technology course of Fashion Design students, Medan State University developed using Computer base learning (CBI) and to find out the learning outcomes of Fashion Technology students of Dressing Education Study Program. This research is done because of the gaps that arise in student learning outcomes because of the lack of balanced mastery of theoretical and practical competencies in students, in addition to the constraints in the learning process, including because the material achievements are very limited, student activity is still low, the learning model used is not appropriate, and learning still uses the teacher center learning method, the use of learning media that has not varied, it is a major obstacle for students in achieving their competence. The purpose of using discovery learning models is to help students in learning, as well as providing practical-realistic opportunities for lecturers and students for independent learning, useful and continuously developing, and increasing student flexibility, by combining the best aspects of face to face and learning. The advantages of discovery learning models help students improve cognitive skills and processes. The data collected from the results of product trials is used as a basis for determining effectiveness, and attractiveness of products developed before being used in the field. The results of the trial of material experts showed a percentage (78.33), were in good enough qualification, so that the CBI media needed to be revised. Learning design experts judge CBI media to be in the percentage (82.33\%). This percentage is in good qualification, which means it needs a little revision. The percentage of instructional media experts is almost the same as teach design experts, namely (82.85\%). This means that the Computer Base Learning (CBI) media are in good qualifications and need a little revision. During the individual trials involving five students, the results of the assessment showed a percentage (74.33\%). This means that the CBI media is in sufficient qualification and needs sufficient revision. Field test results with a percentage (82.14\%) by students and $(87.27 \%$ ) by lecturers. Both are in good qualifications, so CBI Media needs a little revision. The expected result of this study is the increase of student competence in the Fashion Technology course through discovery learning models with a computer base learning (CBI) approach as a medium.
\end{abstract}

Keywords: Discovery Learning Model. Computer Base Learning Media and Fashion Technology 


\section{Introduction}

The Fashion Technology course is a basic course in the Fashion Study Program, whose content includes the introduction and operation of sewing machines, the introduction of basic stitches in sewing, the introduction of basic materials, the introduction of sewing techniques, received by first semester students. Based on observations in the learning process of the Fashion Technology course, it is seen that: 1) lecturers need the right learning model in the learning process so that learning is more effective. Previously the learning model that took place was still carried out conventionally which was supplemented by giving assignments and demonstrations. Learning like this makes the lecturer dominate learning activities so that it creates limited space for students, 2) Students make the lecturer the only source of information so that learning only prioritizes congenital aspects, without regard to affective and physical aspects. Students tend to keep all the difficulties encountered while studying without any effort to solve them. When learning students tend to be passive and as if they have understood what has been taught, 3) Laboratory learning time is limited, so the lecturer only pursues the target so that the material delivered is completed on time, the rest of the students are given homework assignments.

Furthermore, interviews were conducted with several students, saying that 1) in the learning process of fashion technology there were still many students who did not understand about sewing machines and there were even some students who were not good at operating sewing machines, sewing techniques and the basics of sewing and stitching This is because the material is only conveyed with conventional learning without media that can attract students to learn, 2) Conventional learning models using power point media that are still very simple and monotonous are not in accordance with the curriculum that has been applied that learning is student-centered.

Computer Based Intrusion (CBI) learning activities are general terms for all learning activities that use computers, both in part and in whole? Computer Based Instruction (CBI) is used with the function as an individual learning system. CBI software development must consider the principles of learning, the principles of planning a learning system, and the principles of individual learning. In CBI students interact directly with computer-based interactive media, while teachers act as modelers and learning programmers (Rusman, 2012).

The application of CBI in practice can be taken in various ways, if seen from the application of the way of presentation and the objectives to be achieved, including: 1) Model Drills, 2) Tutorial Models, 3) Simulation Methods, 4) Instructional games models. The tutorial model is learning guidance in the form of providing guidance, assistance, guidance, direction and motivation so that students learn effectively and efficiently. In tutorial learning, computers act as lecturers so that all interactions occur between computers and students while lecturers are only facilitators and monitors (Arsyad, 2015).

With the use of discovery learning models with Computer Based Instruction (CBI) learning media, students are expected to easily absorb material, so that learning objectives are achieved. The effectiveness of learning is easy with the development of computer technology that supports learning programs, as expressed by Robert, Hinich, Molenda and James D Russell (2001) states that "computer systems can delivery by enabling them to interact with the lesson program into the system: this is referred to computer based instruction. "Computer systems can deliver learning individually and directly to students by interacting with teaching materials programmed into computer systems, this is what is called computer-based learning.

Computer Based Intrusion learning media is a medium that arouses students' interest in Fashion Technology courses, because this learning model is expected to help lecturers in 
presenting material, so that lecturers and students are more motivated, active and easy to understand the material. This research is an effort to develop the Discovery Learning model by utilizing Computer Based Intrusion (CBI) media in Fashion Technology courses in the Fashion Study Program of Medan State University.

\section{Literature Review}

\subsection{Discovery Learning Model}

Discovery Learning Model According to Bruner, learning by discovery, where students are faced with a problem or situation that seems odd so that students can find a way of solving (Markaban, 2006). Discovery learning model tries to lay the foundation and develop a scientific way of thinking, students are placed as the subject of learning, and the role of the teacher in the Discovery learning model is the learning guide and learning facilitator. Bruner's basic idea is the opinion of Piaget which states that students play an active role in learning. The Discovery Learning model is understanding concepts, meanings, and relationships, through an intuitive process to finally come to a conclusion (Budiningsih, 2005). Discovery is done through observation, classification, measurement, prediction, determination, and inferior. The process is called cognitive process while Discovery itself is the mental process of assimilating concepts and principles in the mind (Robert B. Sund in Malik, 2001). Discovery learning has the same principles as inquiry. There are no principal differences in both of these terms, in Discovery Learning emphasizes more on the discovery of concepts or principles that were previously unknown.

Applying the Discovery Learning model, the lecturer acts as a mentor by providing opportunities for students to actively study, as the opinion of lecturers must be able to guide and direct student learning activities in accordance with the objectives (Sardiman, 2012). This condition aims to change teacher-oriented teaching and learning activities to be student oriented. Discovery learning model of teaching materials is not presented in the final form, students are required to carry out activities gathering information, comparing, categorizing, analyzing, integrating, reorganizing materials and making conclusions.

Learning Objectives of Discovery Learning from various opinions namely by the discovery according to Bell (1981), namely: a) natural discovery students have the opportunity to be actively involved in learning. The reality shows that student participation in learning increases when discovery is used, b) Through learning with discovery, students learn to find patterns in concrete and abstract situations, also many students foresee (extrapolate) additional information provided, c) Students also learn to form a question and answer strategy who are not ambiguous and use question and answer to obtain information in deciding something objectively.

The preparation step of the discovery learning model (Discovery Learning) (Suciati\&PrasetyaIrawan in Budiningsih, 2005) are: 1) Determining learning objectives 2) Identifying student characteristics (initial abilities, interests, learning styles, etc.) 3) Selecting the subject matter. 4) Determine topics that students must learn inductively (from examples of generalization) 5) Develop learning materials in the form of examples, illustrations, tasks and so on for students to learn 6) Organize lesson topics from simple to the complex, from the concrete to the abstract, or from the active, iconic to the symbolic stage. 7) Assessing student learning processes and outcomes. 


\subsection{Learning Outcomes of Clothing Technology}

Learning outcomes are changes in behavior in students that can be observed and measured in the form of knowledge, attitudes and skills. These changes can be interpreted as better previous improvements and developments that do not know to know (Hamalik, 2008). Learning outcomes are patterns of deeds, values, understanding, attitudes, appreciation and skills (Suprijono, 2014). Learning outcomes include cognitive, affective, and psychomotor abilities. Cognitive domains are knowledge (knowledge, memory), comprehension (understanding, explaining, summarizing, examples), application, analysis (outlining, determining relationships), synthesis (organizing, planning, forming new buildings), and evaluating. Affective domain is receiving, responding, valuing, organization, characterization. Psychomotor domains include initiatory, pre-routine, routinized. Psychomotor also includes productive, technical, physical, social, managerial, and intellectual skills (Bloom in Suprijono, 2010).

Fashion Technology Material is a skill that studies methods or techniques, methods of making or finishing clothing. Objectives of Fashion Technology Courses; 1)To provide knowledge and skills to students in taking fashion technology courses. 2) Students can know, understand and operate large and small sewing tools. 3) Students know part of the settlement technique using hands and some use sewing machines. The preliminary study was carried out in the study (Dina 2014 and 2015) in the textile knowledge subject, the ADDIE learning model was developed with the development of digital modules using the Edmodo application, the results of which were very satisfying for students, stated that in this study students could improve their learning outcomes maximally, and motivate student learning can develop.

\section{$3 \quad$ Research Methodology}

The study was conducted in the Fashion Technology Study Program of Universitas Negeri Medan Fashion Design Education Program, namely the development of the Discovery Learning model with the help of Computer Base Learning (CBI) media, in Fashion Technology courses that use the IQF curriculum. The development model used in the development of this Fashion Technology learning model is to utilize CBI as a medium of teaching material. The test subjects at this stage were three material experts, three learning design experts and learning media experts. The data collected through the formative evaluation are grouped into four parts, namely: (1) first stage evaluation data in the form of test results of subject content experts, learning design experts, and instructional media experts, (2) second stage evaluation data in the form of test results data try individuals and field trials, in the form of data from reviews of students and lecturers of Fashion Technology.

This design phase is carried out, first, formulating learning objectives that are SMAR (specific, measurable, applicable, and realistic), compiling learning outcomes, and the work done. Next compile the test, in accordance with the learning objectives that have been formulated. Then determine the learning strategy, CBI Computer Base Learning media.

The steps of the development stage are: 1) Potential and Problems, including: (a) identification of learning problems/needs and determining standards of material competence; (b) conduct learning analysis; (c) identify the characteristics of the initial student and needs analysis; (d) compile basic competencies, indicators and learning outcomes (e) compile tests; 
(f) compile a learning model that is realized in the form of a syllabus and learning design; and (g) developing lesson material, 2) Determining product models, including: (a) adjusting learning models that are in line with student learning characteristics; (b) developing fashion technology teaching materials; (c) Determine discovery learning models, 3) Collection of materials, including: (a) collection of materials / materials; (b) drawing and animation; (c) recording and audio collection, 4) Creating a software model, which includes: (a) software modeling; (b) making manuscript; (c) making storyboards (d) making flowcharts, 5) Developing and making discovery learning models: (a) Model production planning; (b) the production process of the tutorial program; (c) questions and answers; (d) response assessment; (e) reciprocal response; (f) repetition; (g) segment of lesson settings; (h) closing, 6) Review and product testing phase I, stage II, stage II.

Test data is used to determine wealth, effectiveness, and attractiveness of the product being developed. Types of data are: (1) aspects of learning and the correctness of the contents are obtained from material experts and learning designs; (2) media and learning designs are obtained from media experts; (3) the quality of the display and presentation of material, obtained from individual trials, small groups, medium groups, and large groups; (4) the power of dance on multimedia-based learning media is obtained from the activities and responses of students during the learning media trials.

\section{$4 \quad$ Results And Discussion}

The results of the questionnaire dissemination of needs found that $(62.75 \%)$ of the students stated that they really needed the development of Learning Model assisted by Computer Base Learning Media in the learning of fashion technology and (95\%) the lecturers said that they needed the development of Discovery Learning model as an additional modification of teaching methods. improve learning that is more effective and interesting.

Based on the results of the needs analysis, it was concluded that the development of discovery learning model assisted by CBI media was still very much needed by lecturers and students in the fashion technology learning activities. The initial product of discovery learning model developed in broad outline contains material components with discovery learning model design. To obtain complete data used as material for product revisions, the initial CBI product was tested. The stages of product trials were carried out as follows: (1) validation by material experts, (2) validation by learning design experts and media experts, (3) small group trials of 5 students, (4) revision I by validator material expert, expert learning design and media experts, (5) medium group trials, (6) revision II by validator material experts, learning design experts and media experts, (7) field class trials by 32 students, (8) expert revisions material, learning design experts and media experts, (9) final products.

Based on product validation through a series of trials and revisions conducted, the Computer Base Instructional (CBI) products on Sewing Machine Recognition competencies are valid. The trial was carried out in 2 stages: (1) evaluation of material experts, teaching media experts, (2) field trials. The results of the validation in the form of a score of assessment of the components of Computer Base Instructional Media (CBI) development of fashion technology learning on all aspects include: the feasibility of material content, the feasibility of presenting learning, and the feasibility of language seen in table 1. 
Table 1. Score of assessment by material experts about the feasibility of content.

\begin{tabular}{|c|c|c|c|c|}
\hline No. & Indicator Assessment & Respondents & Score & Criteria \\
\hline 1. & $\begin{array}{l}\text { Clarity of learning objectives for fashion } \\
\text { technology }\end{array}$ & 5 & 100 & $\begin{array}{l}\text { Very } \\
\text { good }\end{array}$ \\
\hline 2. & Truth and accuracy of the material & 5 & 100 & $\begin{array}{l}\text { Very } \\
\text { good }\end{array}$ \\
\hline 3. & Accuracy of material coverage & 4 & 80 & Good \\
\hline 4. & $\begin{array}{l}\text { Depth of learning materials for fashion } \\
\text { technology. }\end{array}$ & 4 & 80 & Good \\
\hline 5. & $\begin{array}{l}\text { The truth of the concept of fashion } \\
\text { technology }\end{array}$ & 5 & 100 & $\begin{array}{l}\text { Very } \\
\text { Good }\end{array}$ \\
\hline 6. & $\begin{array}{l}\text { Accuracy of the order of fashion technology } \\
\text { learning material }\end{array}$ & 4 & 80 & Good \\
\hline 7. & Attracting fashion technology material & 4 & 80 & Good \\
\hline \multicolumn{2}{|c|}{ Average } & & 88,6 & $\begin{array}{l}\text { Very } \\
\text { Good }\end{array}$ \\
\hline
\end{tabular}

The results of material validation in the form of a score of assessment of the material components in the discovery learning model assisted by computer base learning (CBI) seen from table 2 below.

The assessment results of material experts include aspects of content feasibility, presentation feasibility and language feasibility in the development of discovery learning models in fashion technology consisting of several topics: (1). Introduction to Sewing Machines, (2). Sewing Machine Operation, (3). Introduction to Basic Skewers, (4). Introduction of the type of seams, layers and decomposition, (5). Maintenance of sewing machines

Table 2. Score of assessment by experts on presentation material.

\begin{tabular}{clccc}
\hline No. & \multicolumn{1}{c}{ Indicator Assessment } & Respondents & Score & Criteria \\
\hline 1. & $\begin{array}{l}\text { Preliminary quality in discovery learning } \\
\text { models }\end{array}$ & 4 & 80 & Good \\
\hline 2. & $\begin{array}{l}\text { The quality of presentation of material in the } \\
\text { fashion technology course. }\end{array}$ & 5 & 100 & $\begin{array}{c}\text { Very } \\
\text { Good }\end{array}$ \\
\hline 3. & $\begin{array}{l}\text { Involvement and role of students in learning } \\
\text { activities }\end{array}$ & 4 & 80 & Good \\
\hline 4. & Feedback quality & 4 & 80 & Good \\
\hline 5. & Material presentation time & 4 & 80 & Good \\
\hline
\end{tabular}




\begin{tabular}{ccccc}
\hline 6. $\begin{array}{l}\text { Quality tests or questions on Clothing } \\
\text { Technology }\end{array}$ & 5 & 100 & $\begin{array}{c}\text { Very } \\
\text { Good }\end{array}$ \\
\hline & Average & 88,6 & Good \\
\hline
\end{tabular}

Table 3. Score of assessment by design experts about presentation.

\begin{tabular}{|c|c|c|c|c|}
\hline No. & Indicator Assessment & Respondents & Score & Criteria \\
\hline 1. & Motivation & 4 & 80 & Good \\
\hline 2. & Clarity of description of fashion technology material & 5 & 100 & $\begin{array}{l}\text { Very } \\
\text { Good }\end{array}$ \\
\hline 3. & Clarity of the examples given in the module & 4 & 80 & Good \\
\hline 4. & Use of new information & 4 & 80 & Good \\
\hline 5. & Feedback on test results for students & 5 & 100 & $\begin{array}{l}\text { Very } \\
\text { Good }\end{array}$ \\
\hline 6. & Maximizing the learning process & 4 & 80 & $\begin{array}{l}\text { Very } \\
\text { Good }\end{array}$ \\
\hline & Average & & 86,7 & Good \\
\hline
\end{tabular}

Table 4. Score of assessment by media experts about the feasibility of content

\begin{tabular}{clccc}
\hline No. & \multicolumn{1}{c}{ Indicator Assessment } & Respondents & Score & Criteria \\
\hline 1. & $\begin{array}{l}\text { The accuracy of the selection of Standard } \\
\text { Competency and material for fashion technology }\end{array}$ & 5 & 100 & $\begin{array}{c}\text { Very } \\
\text { Good }\end{array}$ \\
\hline 2. & $\begin{array}{l}\text { Suitability of fashion technology material with } \\
\text { learning indicators }\end{array}$ & 4 & 80 & Good \\
\hline $3 . \quad$ Providing training in the form of quizzes & 5 & 100 & $\begin{array}{c}\text { Very } \\
\text { Good }\end{array}$ \\
\hline & Average & & 93,3 & Very \\
& & & Good
\end{tabular}

Based on the results of the validation of instructional media experts that the feasibility of the content of the development of discovery learning model design is considered very good, namely the accuracy of the selection of Basic Competency and Competency Standards and the material of fashion technology and the provision of training.

The material expert assessed CBI media development in fashion technology learning based on the above three aspects, namely aspects of content feasibility (88.6\%), presentation 
aspects $(86.7 \%)$, and language feasibility aspects $(85 \%)$, overall these three aspects are categorized verygood. The percentage of the results of expert material research is shown in Figure 1 below:

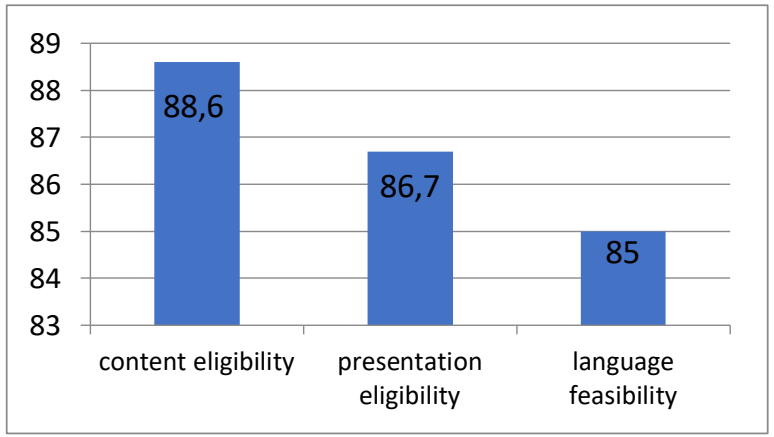

Fig. 1. Score acquisition CBI media development in learning fashion technology by material experts.

Based on the responses of the learning design experts said that the Computer Base Learning (CBI) media in the learning of fashion technology generally shows very good and acceptable but there are some suggestions and input to improve the feasibility of the product. The percentage of the results of the learning media expert assessment can be seen in Figure 2 below.

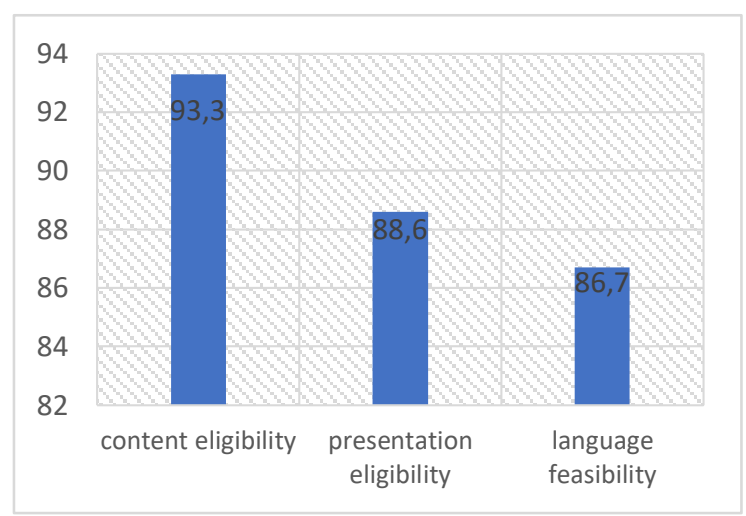

Fig. 2. Computer Base Learning (CBI) media scores by instructional media experts.

The results of the assessment in the small group trial on 5 students based on three aspects, namely the feasibility aspect of the content (57.3\%), presentation eligibility $(58.9 \%)$ and language eligibility $(60 \%)$. Overall included in the category "enough". Percentage of small groups is seen in Figure 3 below. 


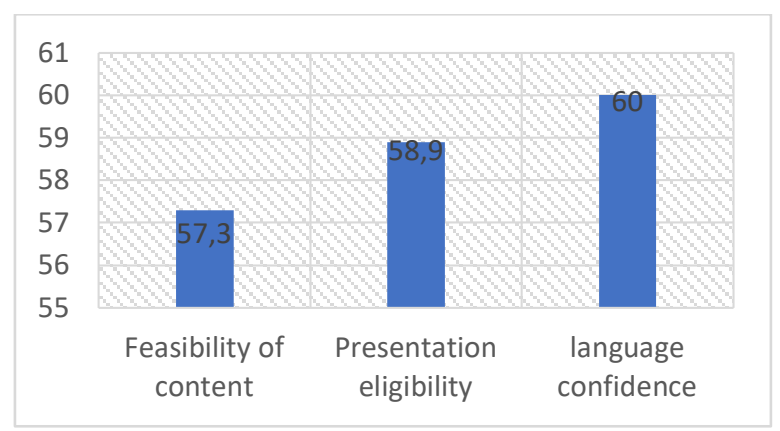

Fig. 3. Score of Computer Base Learning (CBI) media on learning fashion technology in small group trials

The results of the evaluation of the development of Computer Base Learning (CBI) media in the learning of fashion technology showed that the products developed were suitable for use and there were suggestions for improvement so that the development continued in the group trial being revised II. The average percentage of assessment results in the medium trial is based on three aspects, namely the aspect of $70 \%$ content feasibility, $75 \%$ presentation eligibility and $77.6 \%$ language feasibility. Overall included in the good category.The percentage of assessment in the large group/field trial in 32 students was based on three aspects, namely $93.3 \%$ of the content feasibility aspects, $93.8 \%$ presentation eligibility and $91.6 \%$ language feasibility. Overall included in the excellent category.

The results of the evaluation of Computer Base Learning (CBI) media in the learning of fashion technology were stated to be very good and there were no suggestions for improvement so no fourth revision was made. It can be seen from the small class trial, the medium to large class trials/field trials have increased from the response of students, in Figure 4 below.

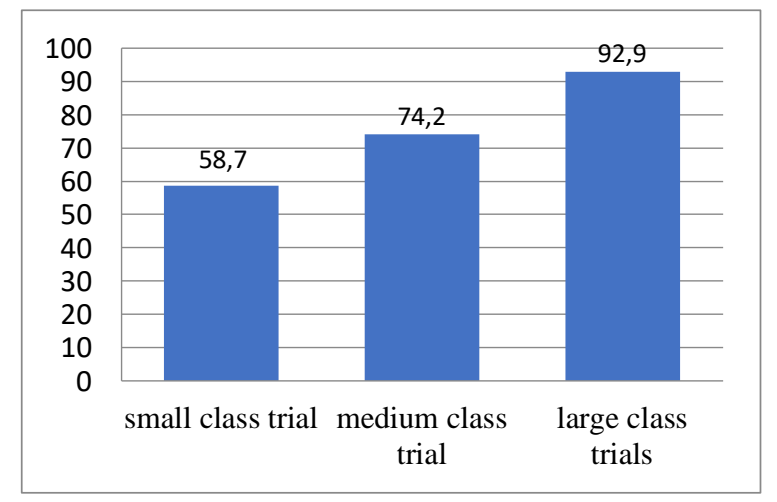

Fig. 4. Average acquisition of scores from small group trials, medium group and large group / field as a whole

The revised and refined aspect is based on data analysis and testing and includes suggestions from material experts, learning design experts and instructional media experts and lecturers and students as CBI media users. The findings obtained during the research included 
that in the learning of Fashion Technology, not all material can be delivered by lecture method alone, but there are several materials that require varied methods, strategies, approaches or learning models that make students more active and motivated. To learn many stimuli should be given to students in order to interact with the environment actively, find and find various things in learning. From the findings, the researchers chose the discovery learning model, because through the model students conducted experiments, learning would be more interesting with experiments, because with experiments, making their own discoveries, not only theories accepted by students but there was continuity and proof between theory and fact. The above explanation in accordance with the advantages of the discovery learning model is expressed by (Divine, 2012) namely with this model the activities and experiences are carried out directly so that it attracts attention to learning and allows the formation of abstract concepts that have meaning, and gives many opportunities for students to be directly involved.

The application of the discovery learning model is adjusted to Bruner's constructivism theory which includes the idea of learning as an active process in which learning is able to form new ideas based on what their current knowledge is and their past knowledge. The phrase in Ampera's writing (2018) that learning to use an appropriate learning model will facilitate maximum competency achievement. With this model can also change what students initially understand abstractly into concrete. Learning by applying the discovery learning model has indirectly carried out what actually must exist in learning, namely providing direct experience in the introduction of sewing machines, making observations, understanding the results of observation, and applying concepts.

\section{Conclusion}

Based on the results of development research carried out and discussions that have been described can be concluded in the study namely; 1) In the study of the development of fashion technology learning was carried out in seven stages, namely the needs analysis stage, the initial product development stage, the expert validation and revision stages, the small group trial stage, the medium group testing stage, the large group/field trial stage and the product stage end. 2) Based on the results of research on Computer Base learning media (CBI) learning the fashion technology assessment from media experts, material experts and experts in overall learning design in very good criteria. 3) Based on the results of student response questionnaires that have been conducted, the Computer Base Learning (CBI) media learning media received responses in the criteria strongly agree that the learning media attract attention, increase learning interest, motivate students and look attractive so that the media is declared effective used as media Computer Base Learning (CBI) learning in fashion technology courses in the Fashion Design Education Study Program.

\section{References}

[1] Akbar, S.: Pengembangan Kurikulum dan Pembelajaran Ilmu Pengetahuan Sosial. (2011)

[2] Ardhana, I W.: Konsep Penelitian Pengembangan dalam Bidang Pendidikan dan Pembelajaran. Makalah disampaikan pada Lokakarya Nasional Angkatan II Metodologi Penelitian Pengembangan Bidang Pendidikan dan Pembelajaran (2002)

[3] Ampera, D.: Adeobe Flash CS6-Based Interactive Multimedia Development for Cloting Pattern Making.Advances in Social, Educations and Humanities Research. Vol. 103 (2017) 
[4] Ampera,D.: Addie Model Through The Task Learning Approach In Textile Knowledge Course In Dress-Making Education Study Program Of State University Of Medan. Vol. 12, pp. 109-114. International Journal of GEOMATE (2017)

[5] Ampera,D.: Student Learning Strategy and Soft-skill in Clothing Business Management. Published under licence by IOP Publishing Ltd. Vol. 306. IOP Conference Series: Materials Science andEngineering (2018)

[6] Arikunto, S.: Prosedur Penelitian Suatu Pendekatan Praktek (2010)

[7] Bell, Fredrick H.: Teaching and Learning Mathmatics (In Secondary School) (1981)

[8] Borg, W.R., Gall, M.D.: Educational Research: An Introduction 4th Edition (2003)

[9] Budiningsih, Asri.: Belajar dan Pembelajaran (2005). Belajar dan Pembelajaran (2006)

[10] Hamalik, Oemar.: Kurikulum dan Pembelajaran (2007)

[11] Margono.: Metodologi Penelitian Pendidikan (2010)

[12] Meltzer, David.: "The Relationship Between Mathematics Preparation And Coceptual Learning Gains In Physics A Possible Hidden Variabel In Diagnostics Pretst Score". Vol. 70. American Journal Physics (2002)

[13] Romiszowski, A.J.: System Approach to Design and Development. Dalam Plomp, T. \& Ely, D.P. (editor in chiefs). pp. 37-43 (1996)

[14] Sardiman, A.M.: Interaksi dan Motivasi Belajar Mengajar (2012). Statistik Parametrik untuk Penelitian Kuantitatif (2013)

[15] Seels, B. B., Richey, R. C.: Instructional Technology (1994)

[16] Sudjana, Nana.: Penilaian Hasil Proses Belajar Mengajar (2010)

[17] Sugiyono.: Metode Penelitian Pendidikan Pendekatan Kuantitatif, Kualitatif, dan R \& D (2013)

[18] Suharsaputra, U.: Metode Penelitian Kualitatif, Kuantitatif dan Tindakan (2013)

[19] Suprijono, Agus.: Cooperative Learning Teoridan Aplikasi PAIKEM (2014)

[20] Syah, Muhibbin.: Psikologi Belajar (2004)

[21] Wardoyo, Mangun, S.: Pembelajaran Konstruktivisme (2013)

[22] Winataputra, Udin S.: Teori Belajar dan Pembelajaran (2008) 